\title{
A cesariana e a ausência de aleitamento materno antes de 6 horas de vida estão associadas com sobrepeso aos 2 anos de idade?
}

\section{Is cesarean section and absence of breastfeeding before 6 hours of age associated with overweight at 2 years of age?}

\author{
José Dias Rego ${ }^{1}$ \\ 'Sociedade de Pediatria do Estado do Rio de Janeiro
}

$\mathrm{O}$ artigo Tipo de parto e aleitamento precoce: impacto no estado nutricional da criança com 24 meses, de Senra et al., publicado neste fascículo da Revista de Pediatria SOPERJ, destaca a importância dos primeiros mil dias de vida, que compõem um período de janela de oportunidades no qual o corpo é modelado para responder a estímulos externos, podendo determinar agravos à saúde ainda na infância, como o desenvolvimento de excesso de peso. Analisa o impacto do número de consultas pré-natais, o tipo de parto e o aleitamento materno precoce no estado nutricional antropométrico de crianças de 24 meses, em que apenas o tipo de parto (cesárea) e a ausência de aleitamento materno antes de 6 horas de vida se associaram positivamente com o excesso de peso aos 2 anos de idade, indicando que aqueles fatores interferem na saúde da criança. No entanto, sabe-se que variáveis como as demonstradas não estão ligadas apenas à nutrição do indivíduo, mas a diversos fatores, sugerindo a necessidade de novas pesquisas.

Substituindo, momentaneamente, estudos futuros pela antiga sabedoria, lembramos que "a mãe carrega o filho no útero por nove meses, no colo por dois anos e no coração por toda a vida". Uma decodificação técnica do ditado popular nos mostra a ontogenia facilitadora do vínculo mãe-filho: no útero, a criança recebe tudo o que precisa para o seu crescimento e desenvolvimento através do sangue que chega pelos vasos umbilicais e nesse ambiente ela, a criança, é banhada pelo líquido amniótico, morno a $26^{\circ} \mathrm{C}$, esperando a hora certa para a fantástica cambalhota, encaixando-se na bacia materna; enquanto isso, a mãe prepara-se para recebê-lo, prepara 'o colo' - em torno do sétimo mês de gestação, por estímulos hormonais, um líquido especial, o colostro (verdadeiro alimento-vacina contra doenças) começa a fluir das mamas; então ele nasce, sai do líquido morno e vem para o ambiente externo (muitas vezes descuidadamente frio), o cordão é cortado, (também muitas vezes precocemente), o bebê é literalmente separado de sua mãe, acaba 'o útero' e fisiologicamente deveria começar 'o colo', onde, entre outras coisas, ele fica aquecido, sugando ou lambendo o 'sangue branco', ouvindo as batidas cardíacas e a voz materna - aí se fortalece o 'coração por toda a vida'. ${ }^{1}$

Muitos anos se passam e continuarão passando... O que poderia ter acontecido com esses bebês (permitam-me assim chamá-los)? De que maneira a cesárea e a ausência do aleitamento materno antes de 6 horas de vida facilitaram a separação da mãe, das mamas, do colostro, do calor, do olhar, da voz e do tato? Eles mamaram fórmulas lácteas, algumas até chamadas de 'maternizadas'? Ficaram separados nas primeiras 6 horas de vida e mais ainda?

Os autores, sabiamente, escrevem em suas linhas finais: "A importância destas variáveis não se restringe ao estado nutricional e poderão ser melhor explicadas por estudos futuros".

\section{REFERÊNCIA}

1 Rego JD. Aleitamento materno. 2. ed. São Paulo: Atheneu; 2006. 